\title{
Off farm work in the Peruvian Altiplano: Seasonal and geographic considerations for agricultural and development policies
}

\author{
Cecilia Turin
}




\section{Objective}

- Identify and analyse seasonal patterns of off farm work comparing two Aymara communities from different agroecological zones in the Peruvian Altiplano.

- Research questions:

- What are the characteristics of households that use off farm work as a livelihood strategy?

- What are the characteristics of household members that work off farm?

- When do household members go for off farm work, where do they work off farm, and in which activities they work? 


\section{Different geographic conditions in the Altiplano}
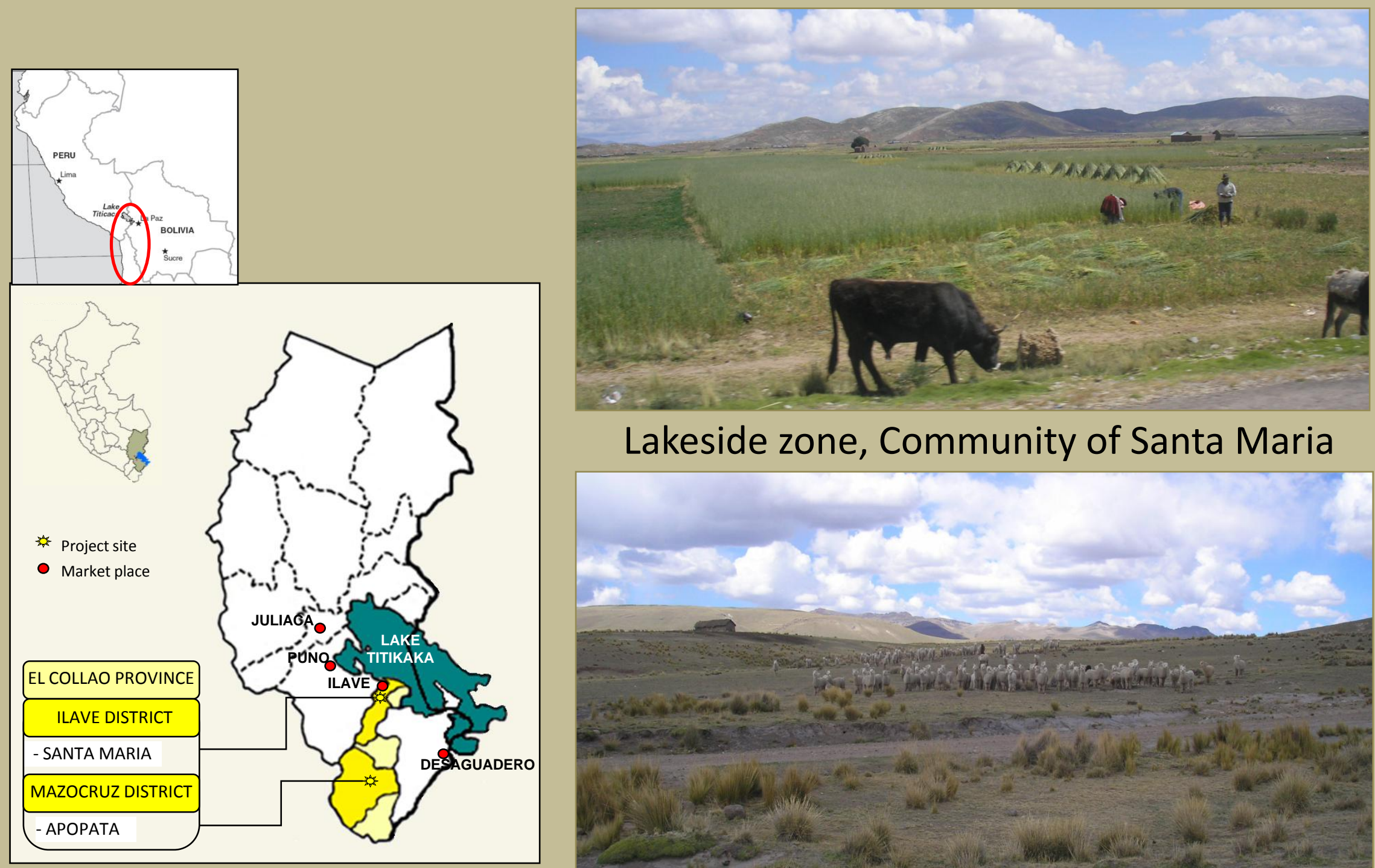

Lakeside zone, Community of Santa Maria

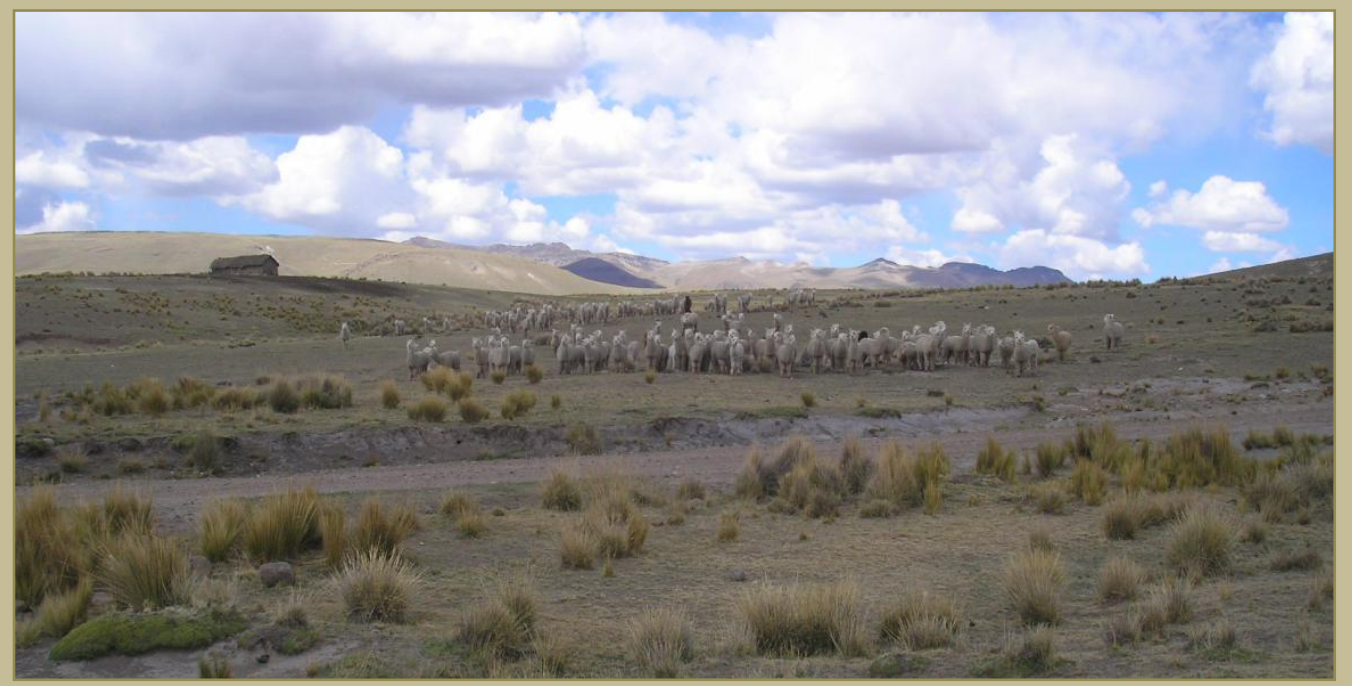

Dry puna zone, Community of Apopata 


\section{Who are they and when do they go for off farm work?}

\begin{tabular}{lcc}
\hline Off-farm work & $\begin{array}{c}\text { Santa Maria } \\
\text { (lakeside) } \\
\mathrm{n}=48\end{array}$ & $\begin{array}{c}\text { Apopata } \\
\text { (dry puna) } \\
\mathrm{n}=67\end{array}$ \\
\hline $\begin{array}{l}\text { \% HH with off farm work } \\
\text { By gender }\end{array}$ & $41.7 \%$ & $34.3 \%$ \\
Female & & \\
Male & $20 \%$ & $13 \%$ \\
& $80 \%$ & $87 \%$ \\
& $100 \%$ & $100 \%$ \\
\hline
\end{tabular}

\begin{tabular}{lcc}
\hline Livelihood strategies & $\begin{array}{c}\text { Santa Maria } \\
\text { (lakeside) } \\
\mathrm{n}=20\end{array}$ & $\begin{array}{c}\text { Apopata } \\
\text { (dry puna) } \\
\mathrm{n}=23\end{array}$ \\
\hline Cropping & $10.0 \%$ & - \\
Livestock & $5.0 \%$ & $91.4 \%$ \\
Mixed-farm (crop.-livest.) & $50.0 \%$ & - \\
Commerce & $25.0 \%$ & $4.3 \%$ \\
Self-employment & $10.0 \%$ & $4.3 \%$ \\
& $100 \%$ & $100 \%$ \\
\hline
\end{tabular}

\begin{tabular}{rcccl}
\hline $\begin{array}{r}\text { Lakeside } \\
\text { Agricultural calendar }\end{array}$ & $\begin{array}{c}\text { Santa Maria } \\
(\mathrm{n}=20)\end{array}$ & Season of the year & $\begin{array}{c}\text { Apopata } \\
(\mathrm{n}=23)\end{array}$ & $\begin{array}{l}\text { Dry puna } \\
\text { Livestock calendaW }\end{array}$ \\
\hline $\begin{array}{r}\text { Weeding \& pest control } \\
\text { Harvest }\end{array}$ & $5.0 \%$ & Jan, Feb, Mar & -- & Alpaca birth \& mating \\
Fallow & $30.0 \%$ & Apr, May, Jun & $26.1 \%$ & Cull \\
Jul, Aug, Sep & -- & Alpaca pregnancy detection \\
& $30.0 \%$ & Oct, Nov, Dec & $8.7 \%$ & Sheering \\
& $25.0 \%$ & Anytime of the year & $52.2 \%$ & \\
& $5.0 \%$ & Whole year & $13.0 \%$ & \\
& $5.0 \%$ & Every Friday & -- & \\
& 100.0 & Total & 100.0 & \\
\hline
\end{tabular}




\section{Where they go and what they do}

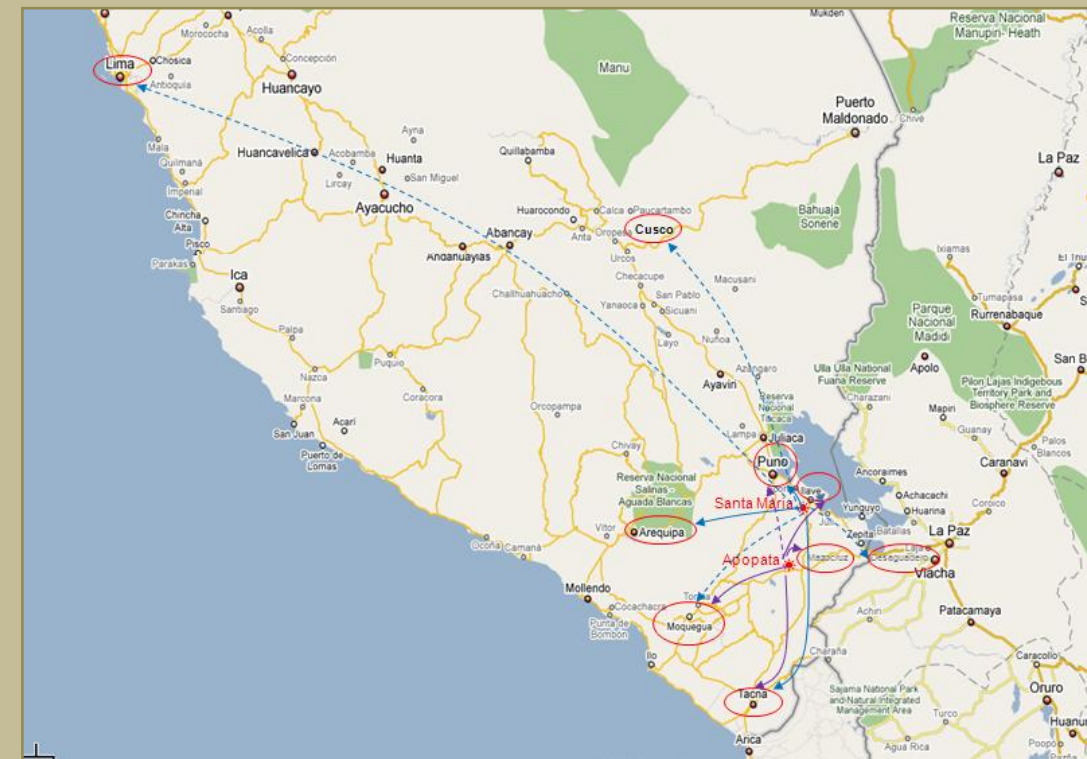

\begin{tabular}{|c|c|c|c|c|}
\hline $\begin{array}{c}\text { Santa Maria } \\
\text { (lakeside) }\end{array}$ & $\begin{array}{c}\text { Distance } \\
\text { (time) }\end{array}$ & Main destination & $\begin{array}{c}\text { Distance } \\
\text { (time) }\end{array}$ & $\begin{array}{c}\text { Apopata } \\
\text { (drypuna) }\end{array}$ \\
\hline $25 \%$ & 1 day & Tacna* & $1 / 2$ day & $47.9 \%$ \\
\hline-- & $1 / 2$ day & Mazocruz & $1 / 2 \mathrm{hr}$ & $17.4 \%$ \\
\hline $20 \%$ & $1 / 2 \mathrm{hr}$ & Ilave & $1 / 2$ day & $13.0 \%$ \\
\hline $20 \%$ & $3 \mathrm{hr}$ & Puno & $1 / 2$ day & $8.7 \%$ \\
\hline $10 \%$ & $1 / 2$ day & Arequipa* & & -- \\
\hline $5 \%$ & 1 day & Moquegua* & $1 / 2$ day & $13.0 \%$ \\
\hline $5 \%$ & 2 day & Lima* & & - \\
\hline $5 \%$ & $11 / 2$ day & Cusco* & & -- \\
\hline $5 \%$ & $1 / 2 \mathrm{hr}$ & Nearby community & & -- \\
\hline $5 \%$ & $4 \mathrm{hr}$ & Desaguadero & & -- \\
\hline $100 \%$ & & & & $100 \%$ \\
\hline
\end{tabular}

* Out of the Altiplano region

\begin{tabular}{lcc}
\hline Activities they work & $\begin{array}{c}\text { Santa Maria } \\
\text { (lakeside) } \\
\mathrm{n}=20\end{array}$ & $\begin{array}{c}\text { Apopata } \\
\text { (dry puna) } \\
\mathrm{n}=23\end{array}$ \\
\hline Agriculture & $50.0 \%$ & $30.4 \%$ \\
Commerce & $15.0 \%$ & $26.1 \%$ \\
Construction & $20.0 \%$ & $17.4 \%$ \\
Transport & $10.0 \%$ & $4.3 \%$ \\
Services & $5.0 \%$ & $13.0 \%$ \\
Education & -- & $4.3 \%$ \\
Mining & -- & $4.3 \%$ \\
& $100 \%$ & $100 \%$ \\
\hline
\end{tabular}




\section{Conclusions}

- In both agro-ecological zones, those who work off farm are mostly male members of the wealthy households who have access to education and a better command of the Spanish language, land and animal holdings, forage, improved animals and hired labour. The poorest remain in the community to work on their own or other farms of the community. This is especially the case of the pastoralist households of the dry puna zone located in remote areas.

- General patterns of off farm work can be different or similar across both agro-ecological zones. Households from lakeside and dry puna agro-ecological zones go to the same places and get involved in almost the same activities. However when looking at the details they do so at different times of the year, according to their agricultural calendars.

- Seasonality and spatial location condition their on-farm labour demands and in turn their offfarm labour availability.

- There is a season when households neither from the lakeside nor the dry puna work off farm: the harvest season for agricultural households of the lakeside zone (May and June) and the alpaca birthing season for pastoralist households of the dry puna zone (January to March), indicating that Altiplano households define their availability of off farm labour according agricultural and cultural activities.

- Current agricultural development policy increases job opportunities in the coastal region acting as pull factor for the wealthier. Policy should increase job opportunities in the local area to provide equal opportunities across households and agro-ecological zones, including seasonal availability of labour according agricultural and livestock calendars to avoid interfering their cultural practices. 